\title{
Races of Puccinia graminis in the United States During 1997 and 1998
}

\author{
D. V. McVey, Research Plant Pathologist, and D. L. Long, Plant Pathologist, Cereal Disease Laboratory, Agricul- \\ tural Research Service, USDA, University of Minnesota, St. Paul 55108; and J. J. Roberts, Retired, Research Plant \\ Pathologist, Cereal Rust Research, Agricultural Research Service, USDA, Georgia Agricultural Experiment Station, \\ Experiment 30212
}

\begin{abstract}
McVey, D. V., Long, D. L., and Roberts, J. J. 2002. Races of Puccinia graminis in the United States during 1997 and 1998. Plant Dis. 86:568-572.

Wheat stem rust caused negligible yield losses in 1997 and 1998. Overwintering sites were found in central and east-central Louisiana in 1997, and in northwestern Florida, northeastern Louisiana, and central Texas in 1998. Race Pgt-TPMK predominated in 1997 with 69\% of 100 isolates with race RCRS next at 11\%. In 1998, race RCRS predominated with 55\% of 132 isolates, and TPMK occurred at 10\%. Race QFCS occurred at 8\% in 1997 and 31\% in 1998. Races QCCS and QTHJ were found in 1997, and races QFBS, RKMQ, RKQQ, and RCMS were found in 1998. Race QCCJ, virulent to barley with the Rpg1 gene for stem rust resistance, was not found from wheat in 1997 or 1998. No virulence was found to wheat lines with $\operatorname{Sr} 13,22,24$, $25,26,27,29,30,31,32,37, G t$, or Wld-1. Oat stem rust was found earlier in 1997 than 1998, but was more widespread in 1998. Race NA27, virulent to $P g-1,-2,-3,-4$, and -8 , was the predominant race in the United States in 1997 (79\% of 116 isolates) and again in 1998 (79\% of 116 isolates). NA16, virulent to $P g-1,-3$, and -8 , was found in the south (1997 and 1998), and NA5, virulent to $P g-2$ and -15 , and NA10, virulent to $P g-2,-3$, and -15 , were found in the west (1997).
\end{abstract}

Additional keywords: oat stem rust, rust races, wheat stem rust

Puccinia graminis has been a major pathogen of small grains worldwide. Since the epidemics of 1953 and 1954, epidemics in the United States have been rare because of the virtual elimination of susceptible Berberis vulgaris L. from cereal producing regions of the northern Great Plains (7). The rust overwinters in the southern United States in the urediniospore growth stage on its respective host. In the spring, it increases and the urediniospores are windborne northward as the host crop renews growth. Resistant wheat (Triticum aestivum L.) cultivars possessing combinations of genes $\mathrm{Sr} 2,6,9 a, 10,17,24,31$, and Wld have provided good protection against the reduced numbers of races since 1954. The development of early maturing cultivars reducing the urediniospore repeating cycle contributes to reduced losses. No major losses from stem rust have occurred in the United States in spring wheat since the

Corresponding author: D. V. McVey

E-mail: donm@cdl.umn.edu

Accepted for publication 8 February 2002.

Publication no. D-2002-0415-01S

This article is in the public domain and not copyrightable. It may be freely reprinted with customary crediting of the source. The American Phytopathological Society, 2002. mid-1950s or in winter wheat since the mid-1960s (6). P. graminis f. sp. tritici race Pgt-QCCL, which first appeared in the Great Plains in 1989, and regarded as a threat to the barley (Hordeum vulgare L.) crop in Minnesota, Manitoba, and the Red River Valley of North Dakota $(12,13)$, constituted just $1 \%$ of the isolates from wheat in 1996 (4), a decline from 26\% in 1995 (3). The majority of the oat (Avena sativa $\mathrm{L}$.) cultivars in the United States are susceptible to race NA27, the most common race of Puccinia graminis $\mathrm{f}$. $\mathrm{sp}$. avenae (1). The trend continues for a single race to dominate most of the pathogen population (10).

This research is part of the continuing effort to monitor changes in race combinations in $P$. graminis that could present a danger to cereal production in North America. When changes in race combinations are recorded, the new race is evaluated, and if necessary, a search for new sources of resistance to the new race is initiated. This paper describes the races of $P$. graminis found on wheat, barley, and oat in 1997 and 1998.

\section{MATERIALS AND METHODS}

Surveys were made over a 22,000-km route covering the Great Plains, Ohio River Valley and Gulf Coast of the United States. The surveys followed a preselected route through areas where small grain cereals are important and rust has historically been a problem. In 1997 and 1998, field surveys of small grain cereals were made in the following areas: southern and central Georgia (late March through May); eastern and southern Texas (early April); northern Texas and south-central Oklahoma (late April); southeastern Gulf Coast (mid-April to early May); southeastern states (early May); Oklahoma and Kansas (mid-May); the Ohio River Valley (early June); northwestern Kansas, Nebraska, western Iowa, South Dakota, and southern Minnesota (mid-June); and Minnesota, North Dakota, and Montana (early July and again in late July). Rust severities were estimated using the modified Cobb scale (5) in commercial fields ( 4 to $50 \mathrm{ha}$ ) every $32 \mathrm{~km}$ in the survey route, or in the first field thereafter. Additional inspections were made at experimental nurseries, demonstration plots, and trap plots containing susceptible wheat, oat, barley, and rye along the route. Techniques used in the surveys and approaches for interpreting results have been described $(8,9,11)$. Whenever rust was observed in a field or nursery, leaves or stems bearing rust uredinia from a single cultivar or field were collected. Additional collections were furnished by cooperators.

Spores from each collection were used to inoculate 7-day-old seedlings of susceptible wheat cvs. Baart (CI 1697) or McNair 701 (CI 15288), oat cv. Marvellous (CI 7027), barley cv. Hiproly (PI 60693), or rye cv. Prolific (CI 26) when the rust forma specialis was known. If the forma specialis was unknown, a pot planted to wheat McNair 701 and Line E (PI 357308), Marvellous oat, Hiproly barley, and Prolific rye was inoculated. Spores suspended in lightweight mineral oil (Soltrol 170) were sprayed on plants, which were then placed in a dew chamber overnight at $18^{\circ} \mathrm{C}$. The inoculated plants had been treated with maleic hydrazide to enhance spore production (16). Following $14 \mathrm{~h}$ of darkness, very high output (VHO) fluorescent light was provided for 3 to $4 \mathrm{~h}$ while the temperature gradually rose to $25^{\circ} \mathrm{C}$ to enhance fungal penetration. Plants were then placed in a greenhouse at 18 to $28^{\circ} \mathrm{C}$, where each culture was maintained in a separate clear plastic chamber. After 12 to 14 days, up to 


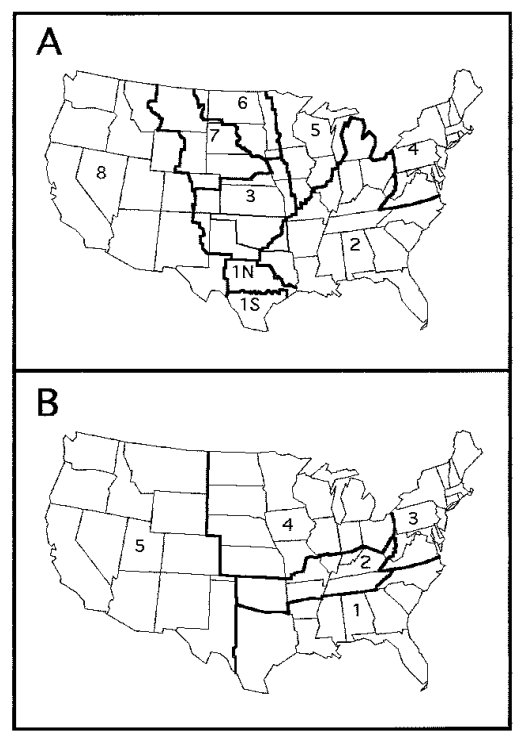

Fig. 1. Agroecological areas for Puccinia graminis in the United States. A, Areas of wheat stem rust: $1 \mathrm{~S}$, fall seeded facultative and spring wheats, overwintering foci; $1 \mathrm{~N}$, mixed winter wheat types, rare overwintering uredinia; 2, soft red winter wheat, scattered overwintering foci; 3 , southern hard red winter; 4 , mostly soft red winter wheat and barberry; 5 , isolated fields of mixed wheat types and barberry; 6 , hard red spring and durum wheat; 7 northern hard red winter; and 8, mostly soft winter wheat, spring wheat, and barberry. B, Areas of oat stem rust: 1, winter oats, occasional uredinia; 2, mixed winter and spring oats, rare overwintering uredinia; 3 , spring oats and barberry; 4, spring oats and barberry; and 5 , isolated oat fields, overwintering uredinia in southern California. four host plants, each bearing one uredinium or pruned to bear one uredinium, were saved. These plants were reincubated (free water, $18^{\circ} \mathrm{C}, 3-\mathrm{h}$ minimum) to eliminate surface contaminants by inducing free urediniospores to germinate and killing them by drying before infection could occur. Approximately 4 days later, cyclone collectors were used to collect urediniospores from three uredinia in separate 00 gelatin capsules (each considered an isolate). Each uredinium provided sufficient spores to inoculate a differential host series.

The second collection of spores was made from each uredinium and bulked with those from other collections made in the same area and at the same time. The bulked spores were inoculated on the "universally" resistant host series.

$\boldsymbol{P}$. graminis f. sp. tritici. The differential host series consisted of wheat lines with single resistance genes $\operatorname{Sr} 5$ (CI 14159), 6 (CI 14163), $7 b$ (CI 14165), $8 a$ (CI 14167), $9 b$ (CI 17386), $9 e$ (Vernstein, University of Sydney, Sydney, Australia), $9 g$ (CnsSr9g), 11 (CI 14171), 17 (Combination VII sel., University of Sydney), 21 (T. monococcum), 30 (PI 330957), and 36 (CI 17385). Races were assigned using the International Pgt-code (16). Additional differential single resistance gene lines consisting of Sr9a (CI 14169), 9d (CI 14177), 10 (CI 17388), and Tmp (CI 13679) were added. The "universally" resistant wheat series consisted of host lines with resistance genes Srl3 (CI 17387), 22 (CI 2433), 24 (CI 17474), 25 (CI 17473), 26 (PI 365582), 27 (CI 14134), 29 (CI 193108), 31 (Line E/Kavkaz), 32 (ER155), 33 (Tetra Can-
thatch/Ae. squarrosa), 37 (W2691/SrTt-2), Gt (PI329230), and Wld-1(Baart/Waldron) and cvs. Era (CI 13986), Cando (CI 17483), and Ward (CI 15892), which were selected over a period of years as resistant to stem rust (13). Data were grouped by ecological areas of the United States (Fig. 1A) based on cultural practices, geographic separation, and wheat production.

$P$. graminis f. sp. avenae. The differential host series for identifying races of $P$. graminis avenae consisted of oat lines with the single resistance genes $P g 1(\mathrm{CI} 9318), 2$ (CI 9319), 3 (CI 9320), 4 (CI 6661), 8 (CI 9321), 9 (CI 9322), 13 (CI 9212), 15 (CI 9351), 16 (CI 822), and $a$ (CI 9139). Races were assigned using the NA race nomenclature (1). The "universally" resistant oat series consisted of the host lines Saia (CI 7010), CI 7221, S.E.S. No. 52 (CI 3034), X-1588-2 (CI 8457), Kyto (CI 8250), MN 730358, and CI 9139, which were selected over a period of years as resistant to stem rust (12). Data were grouped by ecological areas (Fig. 1B) based on oat production, cultural practices, and geographic separation.

\section{RESULTS AND DISCUSSION}

P. graminis f. sp. tritici. The first stem rust was observed in late April in both 1997 and 1998. In 1997, overwintering sites were observed in central and eastcentral Louisiana on cv. Coker 9835, but none were observed in south Texas, while in 1998, they were observed in northwestern Florida on Coker 9835, northeastern Louisiana, and central Texas. By early May 1997, stem rust was observed in

Table 1. Frequency (\%) and source of identified races of Puccinia graminis f. sp. tritici in the United States from wheat by area and source of collections in 1997 and 1998

\begin{tabular}{|c|c|c|c|c|c|c|c|c|c|c|c|c|c|}
\hline \multirow[b]{2}{*}{ Area } & \multirow[b]{2}{*}{ Year } & \multirow[b]{2}{*}{ Source } & \multirow{2}{*}{$\begin{array}{c}\text { Collections } \\
(\text { (no. })^{\mathrm{a}}\end{array}$} & \multirow{2}{*}{$\begin{array}{c}\text { Isolates } \\
\text { (no.) }\end{array}$} & \multicolumn{9}{|c|}{ Races of $P$. graminis f. sp. tritici $^{\mathrm{b}}$} \\
\hline & & & & & QCCS & QFBS & QFCS & QTHJ & RCMS & RKMQ & RCRS & RKRQ & TPMK \\
\hline \multirow[t]{2}{*}{$1 \mathrm{~S}$} & 1997 & Nursery & 1 & 3 & & & & & & & & & 100 \\
\hline & 1998 & Nursery & 0 & 0 & & & & & & & & & \\
\hline \multirow[t]{2}{*}{$1 \mathrm{~N}$} & 1997 & Nursery & 1 & 3 & & & & & & & & & 100 \\
\hline & 1998 & Nursery & 4 & 12 & & & & & & & 100 & & \\
\hline \multirow[t]{4}{*}{2} & 1997 & Field & 1 & 3 & & & & & & & & & 100 \\
\hline & & Nursery & 16 & 45 & & & & 4 & & & & & 96 \\
\hline & 1998 & Field & 1 & 3 & & 100 & & & & & & & \\
\hline & & Nursery & 7 & 21 & & & 14 & & 5 & 5 & 48 & & 29 \\
\hline \multirow[t]{2}{*}{3} & 1997 & Nursery & 0 & 0 & & & & & & & & & \\
\hline & 1998 & Nursery & 2 & 4 & & & 25 & & 25 & & 50 & & \\
\hline \multirow[t]{2}{*}{4} & 1997 & Nursery & 1 & 3 & & & & & & & & & 100 \\
\hline & 1998 & Nursery & 0 & 0 & & & & & & & & & \\
\hline \multirow[t]{3}{*}{5} & 1997 & Field & 1 & 3 & & & & & & & & & 100 \\
\hline & & Nursery & 1 & 3 & 33 & & & & & & & & 67 \\
\hline & 1998 & Nursery & 2 & 6 & & & & & & & 100 & & \\
\hline \multirow[t]{2}{*}{6} & 1997 & Nursery & 12 & 34 & 9 & & 24 & 9 & & & 32 & & 26 \\
\hline & 1998 & Nursery & 22 & 59 & & 2 & 14 & & & & 71 & 2 & 12 \\
\hline \multirow[t]{2}{*}{8} & 1997 & Nursery & 1 & 3 & 100 & & & & & & & & \\
\hline & 1998 & Nursery & 9 & 27 & 4 & & 96 & & & & & & \\
\hline \multirow[t]{3}{*}{ USA } & 1997 & Field & 2 & 6 & & & & & & & & & 100 \\
\hline & & Nursery & 33 & 94 & 7 & & 9 & 5 & & & 12 & & 67 \\
\hline & & Total & 35 & 100 & 7 & & 8 & 5 & & & 11 & & 69 \\
\hline \multirow[t]{3}{*}{ USA } & 1998 & Field & 1 & 3 & & & 100 & & & & & & \\
\hline & & Nursery & 46 & 129 & & 1 & 29 & & 2 & 1 & 56 & 1 & 10 \\
\hline & & Total & 47 & 132 & & 1 & 31 & & 2 & 1 & 55 & 1 & 10 \\
\hline
\end{tabular}

\footnotetext{
${ }^{a}$ Uredinia from a single field, plant, or cultivar constituted a collection from which up to three single uredinia (isolates) were identified.
}

${ }^{\mathrm{b}}$ International $P g t$ races (15): set four included $\operatorname{Sr} 9 a, 9 d, 10$, and $T m p$. 
varietal plots in central Texas and by midMay throughout Louisiana. By the third week of May in 1998, stem rust was observed on the susceptible cv. McNair 701 in southwestern Kansas and during harvest in central Texas. During the first week of June 1997, it was reported in northwestern Arkansas, by mid-June in northern Kentucky and southwestern Illinois, and early July in south-central Virginia. In mid-July 1997, traces were observed on the susceptible cv. Morocco in central South Dakota, and a trace in central North Dakota. By the fourth week of July severities as much as $40 \%$ were reported in plots of susceptible wheat in east-central South Dakota. Also in mid-July, small foci were found on winter wheat cultivars in the Palouse Region of the Pacific Northwest, and by late July, it was severe in some fields of a late maturing, susceptible winter wheat. It was also severe in some fields of a susceptible spring wheat cultivar in eastern Washington and northern Idaho.

In 1998, no new reports were received until late June on the winter wheat cv. 2137 in central South Dakota. However, by early July of 1998, trace amounts of stem rust were reported in eastern South Dakota on the susceptible spring wheat cv. Baart and trace to $20 \%$ severities were observed in winter wheat plots in east-central Minnesota and southeastern North Dakota, but not until mid-July were traces found on the susceptible cv. Max in southeastern North Dakota. By late July, trace to $20 \%$ severities were found in plots on susceptible spring and durum wheat in east-central North Dakota at the soft dough stage. In eastern Washington, stem rust was severe on winter wheat and a few susceptible spring wheat cultivars.

In both 1997 and 1998, only low levels of stem rust overwintered in the southwestern United States, which reduced the quantity of inoculum windborne northward. In 1997, hot dry weather in June also limited infection. In 1997, stem rust incidence was scattered in fields and plots in the lower Mississippi Valley. Light losses occurred only in Louisiana, while development was less than normal in Texas. In 1998, stem rust was generally light and found in plots but not in commercial fields. With the reduction of inoculum and highly resistant spring wheat cultivars in the northern Great Plains, losses to stem rust were negligible. Only in the Pacific Northwest were there moderate losses.

In 1997, six races of wheat stem rust were identified from 100 isolates derived from 35 collections, and in 1998, eight races were identified from 132 isolates of 47 collections (Table 1). This compares with 10 races from 273 isolates from 100 collections in 1996 (4). Race TPMK (69\%) was the most common race in 1997, occurring in all areas except areas 3 and 8, and was identified from field collections only from areas 2 and 5. In 1998, race RCRS $(55 \%)$ was the most common race identiareas 1S, 4, and 8. Race QTHJ was identified from nurseries in areas 2 and 6 in 1997, but was not identified in 1998. No collections were obtained from area 7 in either 1997 or 1998. Races QCCS, RCRS, and TPMK were identified in both 1997 and 1998, and races QFBS, RCMS, and RKMQ were not identified in 1998 but were in 1997. In area 8, race QCCS occurred in both 1997 and 1998. Race QCCJ, fied. However, it was not identified from

which constituted $26 \%$ of the isolates from wheat in 1995 and only $1 \%$ in 1996 , was not identified in 1997 or 1998 . However, race QCCJ was identified from barley once from 13 nursery isolates from area 6, and twice from 3 field isolates from area 8 in 1998 (Table 2).

The frequency of the most common races on wheat in areas 2 and 6 in 1997 and 1998 are shown in Figure 2. Few isolates were obtained from the other areas, so isolates from areas $1,3,4,5$, and 8 are combined for comparison with areas 2 and 6 . Race TPMK, which had been the predominant race in all areas of the United States in recent years, had declined to just 26\% frequency in area 6 in 1997 and 12\% in 1998. In area 2, race TPMK still occurred at $96 \%$ in 1997 but declined to $29 \%$ in 1998. Race TPMK was also common in the other areas of the United States in 1997, but it was not found in those areas in 1998. The decline in race TPMK was accompanied by an increase in race RCRS in all areas and an increase in race QFCS in areas other than area 6.

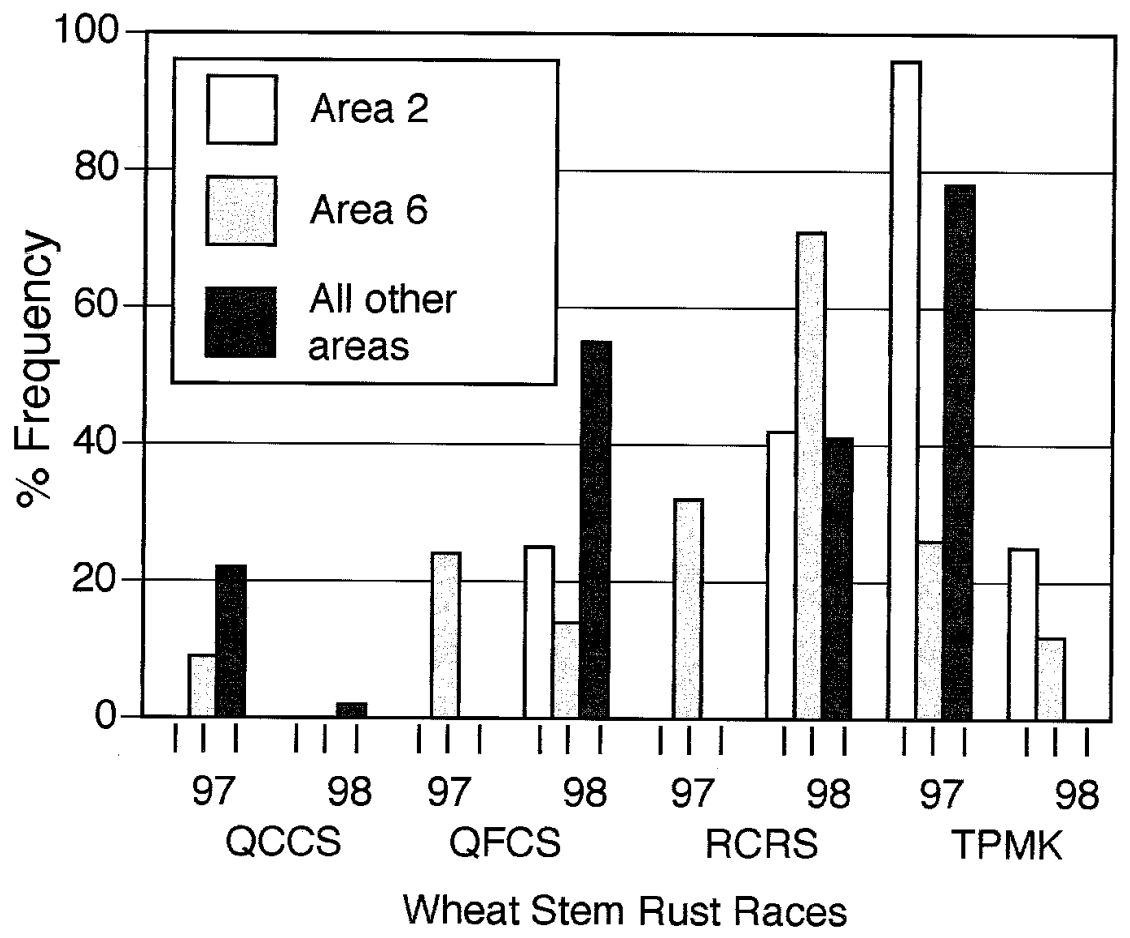

Fig. 2. Comparison of the percent frequency of wheat stem rust races in areas 2 and 6 compared with all other areas.

Table 2. Frequency and source of identified races of Puccinia graminis f. sp. tritici from Hordeum vulgare in 1997 and 1998 in the United States

\begin{tabular}{|c|c|c|c|c|c|c|c|c|c|}
\hline \multirow[b]{2}{*}{ Area $^{a}$} & \multirow[b]{2}{*}{ Year } & \multirow[b]{2}{*}{ Source } & \multirow[b]{2}{*}{ Collections (no.) ${ }^{b}$} & \multirow[b]{2}{*}{ Isolates (no.) } & \multicolumn{5}{|c|}{ Races of $P$. graminis f. sp. trictici ${ }^{\mathrm{c}}$} \\
\hline & & & & & QCCS & QCCJ & QFCS & RCRS & TPMK \\
\hline \multirow[t]{2}{*}{6} & 1997 & Nursery & 3 & 9 & 67 & & & & 33 \\
\hline & & Total & 3 & 9 & 67 & & & & 33 \\
\hline 6 & 1998 & Nursery & 5 & 13 & & 8 & & 92 & \\
\hline \multirow[t]{2}{*}{8} & & Field & 1 & 3 & & 67 & 33 & & \\
\hline & Total & & 6 & 16 & & 19 & 6 & 75 & \\
\hline
\end{tabular}

\footnotetext{
${ }^{a}$ See Figure 1A.

b Uredinia from a single field, plant, or cultivar constituted a collection from which up to three single uredinia (isolates) were identified.

c International Pgt race (15):set four includes $\operatorname{Sr} 9 a, 9 d, 10$, and $\operatorname{Tmp}$.
} 
Races identified from barley in 1997 were QCCS and TPMK. In 1998, in addition to QCCJ, races identified were QFCS and RCRS. The incidence of virulence to single lines used for race identification is shown in Table 3. The decline of race TPMK from 1997 to 1998 from wheat and the increase of race RCRS in 1998 over
1997 can account for the percent changes in virulence to $\operatorname{Sr} 8 a, 9 a, 9 b, 9 e$, and Tmp. No virulence was found for $\operatorname{Sr} 13,22,24$, 25, 26, 27, 29, 30, 31, 32, 37, Gt and Wld-1.

Table 3. Percentage of isolates of Puccinia graminis f. sp. tritici from wheat virulent to the single gene differential wheat lines in the 1997 and 1998 surveys in the United States

\begin{tabular}{|c|c|c|c|c|c|c|c|c|c|c|c|c|c|c|c|c|c|c|c|}
\hline \multirow[b]{2}{*}{ Area } & \multirow[b]{2}{*}{ Year } & \multirow[b]{2}{*}{ Source } & \multirow[b]{2}{*}{ Isolates } & \multicolumn{16}{|c|}{ Differential $S r$ single gene lines } \\
\hline & & & & 5 & 6 & $7 b$ & $8 a$ & $9 a$ & $9 b$ & $9 d$ & $9 e$ & $9 g$ & 10 & 11 & 17 & 21 & 30 & 36 & $T m p$ \\
\hline \multirow[t]{3}{*}{ U.S. } & 1997 & Field & 6 & 100 & 0 & 0 & 100 & 0 & 0 & 100 & 100 & 100 & 100 & 100 & 100 & 100 & 0 & 100 & 100 \\
\hline & & Nursery & 94 & 100 & 5 & 79 & 81 & 28 & 17 & 100 & 67 & 100 & 100 & 69 & 100 & 100 & 0 & 79 & 67 \\
\hline & & Total & 100 & 100 & 5 & 80 & 82 & 26 & 16 & 100 & 69 & 100 & 100 & 70 & 100 & 100 & 0 & 80 & 69 \\
\hline \multirow[t]{3}{*}{ U.S. } & 1998 & Field & 3 & 100 & 0 & 0 & 100 & 100 & 0 & 100 & 0 & 100 & 100 & 0 & 100 & 100 & 0 & 0 & 0 \\
\hline & & Nursery & 129 & 100 & 2 & 69 & 43 & 88 & 56 & 100 & 10 & 100 & 99 & 10 & 99 & 100 & 0 & 64 & 10 \\
\hline & & Total & 132 & 100 & 2 & 67 & 43 & 91 & 55 & 100 & 10 & 100 & 97 & 10 & 99 & 100 & 0 & 67 & 10 \\
\hline $1 \mathrm{~S}$ & 1997 & Nursery & 3 & 100 & 0 & 100 & 100 & 0 & 0 & 100 & 100 & 100 & 100 & 100 & 100 & 100 & 0 & 100 & 100 \\
\hline \multirow[t]{2}{*}{$1 \mathrm{~N}$} & 1997 & Nursery & 3 & 100 & 0 & 100 & 100 & 0 & 0 & 100 & 100 & 100 & 100 & 100 & 100 & 100 & 0 & 100 & 100 \\
\hline & 1998 & Nursery & 12 & 100 & 0 & 100 & 0 & 100 & 100 & 100 & 0 & 100 & 100 & 0 & 100 & 100 & 0 & 100 & 0 \\
\hline \multirow[t]{4}{*}{2} & 1997 & Field & 3 & 100 & 0 & 100 & 100 & 0 & 0 & 100 & 100 & 100 & 100 & 100 & 100 & 100 & 0 & 100 & 100 \\
\hline & & Nursery & 45 & 100 & 4 & 96 & 100 & 0 & 4 & 100 & 96 & 100 & 100 & 100 & 100 & 100 & 0 & 96 & 96 \\
\hline & 1998 & Field & 3 & 100 & 0 & 0 & 100 & 100 & 0 & 100 & 0 & 100 & 100 & 0 & 100 & 100 & 0 & 0 & 0 \\
\hline & & Nursery & 21 & 100 & 5 & 86 & 76 & 100 & 48 & 100 & 29 & 100 & 95 & 29 & 100 & 100 & 0 & 86 & 29 \\
\hline 3 & 1998 & Nursery & 4 & 100 & 0 & 75 & 25 & 100 & 50 & 100 & 0 & 100 & 100 & 0 & 100 & 100 & 0 & 75 & 0 \\
\hline 4 & 1997 & Nursery & 3 & 100 & 0 & 100 & 100 & 0 & 0 & 100 & 100 & 100 & 100 & 100 & 100 & 100 & 0 & 100 & 100 \\
\hline \multirow[t]{3}{*}{5} & 1997 & Field & 3 & 100 & 0 & 100 & 100 & 0 & 0 & 100 & 100 & 100 & 100 & 100 & 100 & 100 & 0 & 100 & 100 \\
\hline & & Nursery & 3 & 100 & 0 & 67 & 67 & 33 & 0 & 100 & 67 & 100 & 100 & 67 & 100 & 100 & 0 & 67 & 67 \\
\hline & 1998 & Nursery & 6 & 100 & 0 & 100 & 0 & 100 & 100 & 100 & 0 & 100 & 100 & 0 & 100 & 100 & 0 & 100 & 0 \\
\hline \multirow[t]{2}{*}{6} & 1997 & Nursery & 34 & 100 & 9 & 62 & 62 & 65 & 41 & 100 & 26 & 91 & 100 & 35 & 100 & 100 & 0 & 62 & 26 \\
\hline & 1998 & Nursery & 59 & 100 & 2 & 85 & 29 & 88 & 73 & 100 & 12 & 100 & 98 & 12 & 98 & 100 & 0 & 85 & 12 \\
\hline \multirow[t]{2}{*}{8} & 1997 & Nursery & 3 & 100 & 0 & 0 & 0 & 100 & 0 & 100 & 0 & 100 & 100 & 0 & 100 & 100 & 0 & 0 & 0 \\
\hline & 1998 & Nursery & 27 & 100 & 0 & 0 & 96 & 100 & 0 & 100 & 0 & 100 & 100 & 0 & 100 & 100 & 0 & 0 & 0 \\
\hline U.S. & $1996^{\mathrm{a}}$ & & & 100 & 1 & 68 & 93 & 33 & 1 & 100 & 66 & 100 & 100 & 67 & 93 & 100 & 0 & 69 & 66 \\
\hline U.S. & $1995^{\mathrm{b}}$ & & & 100 & 0 & 47 & 60 & 31 & 0 & 100 & 39 & 100 & 100 & 39 & 100 & 100 & 0 & 47 & 39 \\
\hline U.S. & $1994^{c}$ & & & 100 & 5 & 48 & 71 & 35 & 8 & 100 & 39 & 100 & 100 & 40 & 100 & 100 & 0 & 48 & 39 \\
\hline U.S. & $1993^{d}$ & & & 100 & *e & 53 & 76 & 19 & * & 100 & 57 & 100 & 95 & 57 & 94 & 100 & 0 & 57 & 5 \\
\hline
\end{tabular}

${ }^{a}$ McVey et al. (4). Includes Hordeum collections.

${ }^{\mathrm{b}}$ McVey et al. (3). Does not include Hordeum collections.

${ }^{\mathrm{c}}$ McVey et al. (2). Does not include Hordeum collections.

${ }^{\mathrm{d}}$ Roelfs et al. (14). Includes Hordeum collections.

$\mathrm{e} *=$ less than $0.6 \%$.

Table 4. Frequency (\%) and source of identified races of Puccinia graminis f. sp. avenae in the United States from oat by area and source of collection in 1997 and 1998.

\begin{tabular}{|c|c|c|c|c|c|c|c|c|c|}
\hline \multirow[b]{2}{*}{ Area } & \multirow[b]{2}{*}{ Year } & \multirow[b]{2}{*}{ Source } & \multirow[b]{2}{*}{ Collections } & \multirow[b]{2}{*}{ Isolates } & \multicolumn{5}{|c|}{ Percentage of isolates per race } \\
\hline & & & & & NA-5 & NA-10 & NA-16 & NA-27 & Other $^{\mathrm{a}}$ \\
\hline \multirow[t]{7}{*}{1} & 1997 & Field & 2 & 6 & & & 33 & 67 & \\
\hline & & Nursery & 23 & 67 & & & 6 & 94 & \\
\hline & & Avena fatua & 1 & 3 & & & & 100 & \\
\hline & & Total & 26 & 76 & & & 8 & 92 & \\
\hline & 1998 & Field & 2 & 6 & & & & 100 & \\
\hline & & Nursery & 32 & 90 & & & 2 & 98 & \\
\hline & & Total & 34 & 96 & & & 2 & 98 & \\
\hline \multirow[t]{2}{*}{2} & 1998 & Nursery & 1 & 3 & & & & 100 & \\
\hline & & Total & 1 & 3 & & & & 100 & \\
\hline \multirow[t]{7}{*}{4} & 1997 & Nursery & 7 & 19 & & & & 100 & \\
\hline & & A. fatua & 1 & 3 & & & & 100 & \\
\hline & & Total & 8 & 22 & & & & 100 & \\
\hline & 1998 & Field & 1 & 3 & & & & 100 & \\
\hline & & Nursery & 8 & 24 & & & & 96 & 4 \\
\hline & & A. fatua & 1 & 3 & & & & 100 & \\
\hline & & Total & 10 & 30 & & & & 97 & \\
\hline \multirow[t]{2}{*}{5} & 1997 & Nursery & 6 & 18 & 33 & 67 & & & \\
\hline & & Total & 16 & 18 & 33 & 67 & & & \\
\hline \multirow[t]{8}{*}{ U.S. } & 1997 & Field & 2 & 6 & & & 33 & 67 & \\
\hline & & Nursery & 36 & 104 & 6 & 12 & 4 & 79 & \\
\hline & & A. fatua & 2 & 6 & & & & 100 & \\
\hline & & Total & 40 & 116 & 5 & 10 & 5 & 79 & \\
\hline & 1998 & Field & 3 & 9 & & & & 100 & \\
\hline & & Nursery & 41 & 117 & & & 2 & 97 & 1 \\
\hline & & A. fatua & 1 & 3 & & & & 100 & \\
\hline & & Total & 45 & 129 & & & 2 & 98 & \\
\hline
\end{tabular}

a Virulent to $P g 1,-2,-3,-4$, and -13 . 
P. graminis f. sp. avenae. Oat stem rust was first observed slightly earlier in 1997 than in 1998. However, it was more widespread in 1998. In 1997, oat stem rust was first observed in mid-February in nursery plots at Beeville, TX. However, by the first week of April, hot spots were found in field and nurseries and on wild oat (Avena fatua) in roadside ditches in trace amounts in central Texas. By late March, it was observed in southern Louisiana, but development was slowed by cool weather. In 1998 , oat stem rust was observed in plots in trace amounts at Beeville and Beaumont, TX and Fairhope, AL in late March. However, a field of oat was practically destroyed by oat stem rust north of Uvalde, TX in late March. During the second week in April 1997, 50\% severities were reported from southwestern Alabama, and during the last week of April overwintering sites were found in oat fields in eastcentral Louisiana, southwestern Alabama, and with trace severities in plots in southern Georgia, southwestern Mississippi and northern Louisiana. By the last week of April 1998, oat stem rust also had become widespread in plots in northwestern Florida, southwestern, east-central, and northeastern Alabama, central and northwestern Louisiana, west-central Mississippi, and north-central Texas. In late May 1998, stem rust severities ranged from 5 to $30 \%$ on some elite oat lines at the Plains Experiment Station in southwestern Georgia. In May 1997, oat stem rust was reported from the Sacramento Valley, CA, but no reports were received in 1998. Not until mid-July 1997 were trace amounts reported in plots from east-central South Dakota, and central and west-central Minnesota. In early July 1998, oat stem rust was observed in eastern South Dakota and a southwestern Minnesota field at trace to $5 \%$ severities. By late July 1988, traces were found in plots and fields in north- western Minnesota and east-central North Dakota.

NA27 (Table 4), virulent to $P g-1,-2,-3$, -4 , and -8 , continued to predominate in areas 1 and 4 in 1997, and areas 1, 2, and 4 in 1998. It constituted $92 \%$ of 76 isolates from 26 collections in 1997, and $98 \%$ of 96 isolates from 34 collections in 1998 from area 1 . With the exception of one isolate virulent to $P g-1,-2,-3,-4,-8$, and -13 , from area 4 in 1998, NA27 was the only race identified from area 4 in 1997 and 1998 and area 2 in 1998. NA27 was the only race identified from wild oat $(A$. fatua) in both years. NA16, virulent to $P g$ $1,-3$, and -8 was identified only from area 1 in 1997 and 1998. This is a relative simple race and lacks virulence to attack common oat cultivars in other areas. In 1997, NA5 and NA10, virulent to $P g-2$ and -16 , and $P G-2,-3$, and -15 , respectively, occurred only in area 5. Oat lines with $\mathrm{Pg}$ $9,-16$, and $-a$ were resistant to all rust isolated from the United States. No virulence was detected to any of the oat lines in the resistant series. Although more inoculum was produced in the southern United States in 1998 than in 1997, the lack of a stem rust epidemic in 1998 was due to the small acreage of oat grown in the central United States, or to unfavorable environmental conditions for development of regional epidemics.

\section{ACKNOWLEDGMENTS}

We thank Mark Hughes for assistance with data analysis, David H. Casper and Lucy Wanschura for technical assistance with the survey.

\section{LITERATURE CITED}

1. Harder, D. E. 1994. Identification of new races of Puccinia graminis f. sp. avena. Plant Dis. 78:367-368.

2. McVey, D. V., Long, D. L., and Roberts, J. J. 1996. Races of Puccinia graminis in the United States during 1994. Plant Dis. 80:8589.

3. McVey, D. V., Long, D. L., and Roberts, J. J.
1997. Races of Puccinia graminis in the United States during 1995. Plant Dis. 81:306310 .

4. McVey, D. V., Long, D. L., and Roberts, J. J. 1999. Races of Puccinia graminis in the United States during 1996. Plant Dis. 83:871875.

5. Peterson, R. F., Campbell, A. B., and Hanna, A. E. 1948. A diagrammatic scale for estimating rust intensity on leaves and stems of cereals. Can. J. Res. C. 26:496-500.

6. Roelfs, A. P. 1978. Estimated losses caused by rust in small grain cereals in the United States - 1918-1976. U.S. Dept. Agric., Agric. Res. Serv. Misc. Publ. No. 1363.

7. Roelfs, A. P. 1982. Effects of barberry eradication on stem rust in the United States. Plant Dis. 66:177-181.

8. Roelfs, A. P. 1985. Epidemiology in North America. Pages 403-434 in: The Cereal Rusts. Vol. II, Diseases, Distribution, Epidemiology and Control. A. P. Roelfs, and W.R. Bushnell, eds. Academic Press, Orlando, FL.

9. Roelfs, A. P. 1990. Epidemiology of the cereal rusts in North America. Can. J. Plant Pathol. 11:86-90.

10. Roelfs, A. P., and Groth, J. V. 1980. A comparison of virulence phenotypes in wheat stem rust populations reproducing sexual and asexually. Phytopathology 70:855-862.

11. Roelfs, A. P., and Long, D. L. 1987. Puccinia graminis development in North America during 1986. Plant Dis. 71:1089-1093.

12. Roelfs, A. P., Long, D. L., and Roberts, J. J. 1993. Races of Puccinia graminis in the United States during 1990. Plant Dis. 77:125128.

13. Roelfs, A. P., Long, D. L., and Roberts, J. J. 1993. Races of Puccinia graminis in the United States during 1991. Plant Dis. 77:129132.

14. Roelfs, A. P., Long, D. L., and Roberts, J. J. 1995. Races of Puccinia graminis in the United States during 1993. Plant Dis. 79:969972.

15. Roelfs, A. P., and Martens, J. W. 1988. An international system of nomenclature of $P u c$ cinia graminis f. sp. tritici. Phytopathology 78: 526-533.

16. Rowell, J. B. 1984. Controlled infection by Puccinia graminis f. sp. tritici. Pages 291-332 in: The Cereal Rusts, Vol. I, Origins, Specificity, Structure, and Physiology. W.R. Bushnell and A. P. Roelfs, eds. Academic Press, Orlando, FL. 